\title{
6. \\ MUVA NA GORNJOJ USNI: \\ NARATIVNI PROSTOR SMRTI \\ U PROZI VLADANA DESNICE
}

\section{Bojan Đorđević}

UDK: 821.163.42-3Desnica, V.:612.013

Izvorni znanstveni članak

Sažetak: U radu se analiziraju narativni postupci u Desničinim pripovetkama Bunarevac i Oproštaj, kao i u završnim poglavljima romana Proljeća Ivana Galeba. Ukazuje se na tanatološki okvir pripovedanja i na postupke koji na višestruki način utemeljuju istorijsku fikciju ovih proznih ostvarenja. Pokazuje se razlika u pristupu narativnim poljima tako što se junak u pripoveci Bunarevac konstituiše kao biće izvan ontološke pozicije shvatanja smrti, dok se junaci pripovetke Oproštaj i romana Proljeća Ivana Galeba iz ravni smrti kao nepostojanja prevode u ravan umiranja kao, paradoksalno, konačnog dokaza egzistencije.

Ključne reči: naracija, smrt, umiranje, telo, prostor, trajanje

I.

D

a je roman Proljeća Ivana Galeba barem jednim svojim delom duboko ukorenjen u tokove srednjoevropske romaneskne i pripovedačke tradicije svedoči amblematična oznaka bolnice kao mesta umiranja. Za razliku od Manovog sanatorijuma - koji jeste, naravno, obeležen bolešću, ali je prvenstveno simbolični kôd vremena i svih temporalnih označilaca - bolnica ili sanatorijum u onom diskursu koji je imanentan i Desnici predstavlja tanatološki okvir. Taj okvir se dalje sužava, u vidu levka, i vodi do mikrotoposa tzv. sobe za umiranje - šterbecimera (nem. Sterbezimmer) - kao svojevrsne granice dvaju svetova. Šterbecimer je tematsko-motivska tačka koju nalazimo i u prozi i u poeziji pisaca nemačkog jezičkog područja, od Gotfrida Bena (pesme Žena umire od raka i Čovek $i$ žena idu kroz baraku za rak) i Eriha Marije Remarka (roman Na zapadu ništa novo) do Tomasa Bernharda (roman Dah). Šterbecimer je, najzad, u Desničinom romanu onaj deo narativnog prostora u kome se stiču dve referentne tačke pripovedanja - fikcionalno i stvarno, tj. ono što je „zamišljeno“ $i$ „realno“. Bolesnik u Desničinom romanu, koji je nesvestan mesta na kome se nalazi, može fikcionalizovati svoj položaj i ljutiti se na svoje sapatnike. No, u 
jednom trenutku - zahvaljujući obaveštenju bolničara - on se suočava sa stvarnim, kao neminovnim „prekoračivanjem granice koja je dotle bila nedostupna stvarnim očima“. ${ }^{1}$ Ontološka pretpostavka za ovakvo suočavanje sa „stvarnim“ jeste, naravno, smrt. Fikcionalni svet kao drugi, odvojen od stvarnog sveta iskustva, ${ }^{2}$ upravo se belodano postvaruje u narativnom pristupu smrti i umiranju. $U$ tome narativnom polju odnos između fikcionalnog sveta i sveta zbilje ponajviše nalikuje alegorijskoj slici dizanja zavese u pozorištu, pri čemu je agonija umiranja zapravo čin spuštanja zavese, posle koje se i književni junak i narator i čitalac iz fikcionalnog sveta „prevode“ u „vrhovnu stvarnost svakodnevnog života“.” Tako pisac zapravo ostvaruje svojevrstan neformalni pristup fikcionalnom diskursu, koji ima svoju logiku koja ne mora nužno odgovarati realnom diskursu. Ono što bi Delejni nazvao „nivoom subjunktivnosti“ “ jeste zapravo naratorovo nastojanje da opažajne i strukturalne postavke naracije što više saobrazi vizuri junakâ, iz koje će se onda izvući implikacija saobražena narativnoj logici. Ovakav pristup procesu umiranja u fikcionalnoj prozi odlično ilustruju pripovetke Vladana Desnice Bunarevac i Oproštaj, kao i završna poglavlja romana Proljeća Ivana Galeba.

\section{2.}

Prikaz Jagodine smrti u pripoveci Bunarevac vrhuni čehovljevsku atmosferu besmisla i uzaludnosti. Miloševo osećanje stida zbog protraćenog života i nemoći da se učini nešto korisno, ${ }^{5}$ tako slično onome Astrovljevom u drami Ujka Vanja, klimaks dostiže u času Jagodine smrti. Narator nije insistirao na detaljima procesa umiranja, ali je utoliko pre eksponovao sliku mrtve Jagode, koja je - sada oslobođena patnje i bola - u tome trenutku sušta suprotnost Milošu koji „,ne osjeća ništa nego goli fakat: mrtva je“. ${ }^{6}$ Mrtva Jagoda upečatljivija je predstava života nego živi Miloš sa svojim malim, neznatnim bolom. Trenutak smrti, pak, ogolio je Jagodu kao objekat - objekat ljubavi, a potom, sve više, objekat besmisla, objekat bolesti, najzad i objekat smrti. A - rečima Edmunda Huserla - „kada se modelira prema nečemu što percipiramo kao objekat, onda je interpretacija nužno naturalistička“? Stoga i Jagoda kao leš, dakle telo u svome ogoljenom vidu, zaprema ceo Milošev vidik, čitavu njegovu percepciju, a samim tim i povlašćeni prostor naracije:

Jagoda je ležala nauznak, otvorenih usta. Ispod gornje usne provirivala su dva sjekutića, suha, bez sjaja, neovlažena slinom, kao da na njima nema cakleni. Kukasti nosić, jasno ocr-

$1 \quad$ Dorrit Conn, Transparent Minds. Narrative Modes for Telling Consciousness in Fiction, Princeton 1978., 84.

2 Videti: Brian McHale, Postmodernist Fiction, New York - London 1987., 26-27.

3 Peter L. Berger - Thomas Luckmann, The Social Construction of Reality. A Treatise in the Sociology of Knowledge, New York 1966., 24-25.

4 Samuel R. Delany, „About 5750 words“, The Jewel-Hinged Jaw. Notes on the Language of Science Fiction, Elizabethtown 1977., 37.

5 „Ali što da čine? Gdje je izlaz? Zar mi znamo gdje je izlaz i što treba da se radi? Što smo s našim vlastitim životom umjeli da učinimo?" Vladan Desnica, „Bunarevac“, Pripovetke, Beograd 1993., 206.

6 V. Desnica, „Bunarevac“, 225.

7 Edmund Husserl, „Ideen zu einer reinen Phänomenologie und phänomenologischen Philosophie“, Jahrbuch für Philosophie und phänomenologische Forschung, 1/1913., sv. 1, 183. 
tan i već kao voštan, oštro se isticao, s jače naglašenom zakrivljenošću; iz njega je izmilila, kao crvak, tanka nit krvi. ${ }^{8}$

Telo postaje objektivitet, egzistencijalna činjenica, koja za Miloša, doduše, predstavlja pretpostavku određenog duševnog i emocionalnog stanja, ${ }^{9}$ ali stanja koje se ispoljava samo na mahove, i u očiglednom nerazumevanju smrti kao golog fakta:

S već pripravljenim ćutilom na osjet studi Miloš pruži ruku i dohvati joj podlakticu. Ipak ga hladan dodir iznenadi, i on se lecne... ${ }^{10}$

Počeo je postepeno prema lešu osjećati neku tuđost - to nije ona, to je samo njeno tijelo, njen simulacrum, prazni simulacrum. ${ }^{11}$

Sa stanovišta junaka još se, dakle, nije desilo ono što se u ravni naracije već zbilo. Smrt je u tim trenucima za junaka još uvek „čista uslovnost“, ${ }^{12}$ neka vrsta iluzije koja mu omogućava konstrukciju paralelne stvarnosti:

A ona, prava ona, gleda odozgo (gore, malo udesno) u njega pognuta i zabavljena nad tijelom. Pade mu na um kako je sasvim pojmljivo što su ljudi došli na pomisao o duši koja napušta mrtvo tijelo i odlijeće uvis. ${ }^{13}$

Emocionalno izmeštanje Jagode iz njenoga tela kao leša na simboličkoj razini predstavlja i čežnju samoga junaka za izlaskom iz oskudnog, bremenitog i jednolikog prostora sobe. Jer, Miloševa i Jagodina soba, po njenom povratku iz sanatorijuma, nije ništa drugo nego šterbecimer! Kao takva, ona pripada tzv. tekstualnom, stvarnom svetu naracije, dok je Miloševa potreba da ženu vidi izmeštenu i oslobođenu tela ništa drugo do kontrafaktualna, hipotetična situacija. ${ }^{14}$ Međutim, trajni boravak junaka u hipotetičnom prostoru nije moguć. Telesne promene koje Miloš uočava na Jagodinom lešu (koji, u vremenu naracije, nije više Jagoda) nisu postepene i sukcesivne, već nagle, istovremene i višestruke. Tako telesne promene usmeravaju i potencijalizuju pravac naracije ${ }^{15}$ kome se, prema zakonitostima pripovedanja, mora povinovati i sam junak. Fizički dokaz toga jeste Milošev neuspeh da obuče mrtvu Jagodu, tj. da se izbori sa mrtvačkom ukočenošću. Tako rigor mortis biva tzv. regulativni model narativnog sveta, ${ }^{16}$ a junak pripremljen da dospe do konačne istine smrti.

Ta istina Milošu se otkriva posredno, u trenutku kada na Jagodinu usnu - koja više ne pripada osobi, već telu - sleće muva:

\footnotetext{
V. Desnica, „Bunarevac“, 225.

Zoltan Kanjo, „Prilog proučavanju početka pripovednog teksta“, Rečc, 2/1995., br. 13, 97.

V. Desnica, „Bunarevac“, 225.

Isto, 227.

12 Lee T. Lemon - Marion J. Reis (prir.), Russian Formalist Criticism. Four Essays, Lincoln 1965., 142.

13 V. Desnica, „Bunarevac“, 227.

14 O ovoj distinkciji opširno: Marie-Laure Ryan, „The Modal Structure of Narrative Universes“, Poetics Today, 6/1985., br. 4, 717-755.

15 O spoljašnjim uslovima za oblikovanje prostora naracije videti: Uri MARGolin, „Individuals in Narrative Worlds: An Ontological Perspective“, Poetics Today, 11/1990., br. 4, 843-871.

16 Paul M. Churchland, „Eliminative Materialism and the Propositional Attitudes“, A Neurocomputational Perspective. The Nature of Mind and the Structure of Science, Cambridge, Massachusetts 1989., 7.
} 
Jedna muha (odakle li se samo stvori?) hodala je po rubu gornje usne. To što muha nesmetano šeta po tako golicavu mjestu, ne izazivajući nikakve reakcije, nikakva pokreta, ni najmanjeg ježura kože, činilo mu je uočljivijom nepomičnost smrti. A time $i$ shvatljivijom samu smrt-njenu mramornu hladnoću i mrtvu nepomičnost. Simulacrum, predmet. ${ }^{17}$

Ojačana junakova svest o simulakrumu kao imitaciji bića, kao subjektivnoj slici o Jagodi, koja se nužno razlikuje od Jagode kao tela, ta svest o diferenciji između stvarnog i ikoničnog, osnažena je gotovo folklornim (jer realističnim) prizorom muve kao označioca smrti. Ovakva „folklorna psihologija“ ${ }^{18}$ koju narator koristi da transcendentira junaka u realiju prihvatanja konačnosti, ospoljena je nižim oblikom života. Nižim, ali nadmoćnim. Toliko nadmoćnim da ga u agoniji i Ivan Galeb priziva u svest kao supstituciju ljudskih glasova nad svojom bolesničkom / samrtničkom posteljom: „Ponekad je šum tih glasova, koji su se oko uboda skupili kao muhe, mutniji i dalji..."19

Dakle, tek fakat muve i nedostatka prirodne, žive reakcije na nadražaj, svedoče smrt kao činjenicu - onu koje junak dotle nije bio dokraja svestan. Ne može se reći da Miloš u tom trenutku doživljava neku vrstu epifanije, ali se, u svakom slučaju, kao živi subjekt sadružuje sa Jagodom kao objektom! Naime, dok je bolovala, Jagoda se postepeno udaljavala od njega, i u emotivnoj i u duhovnoj sferi - pripadala je ne samo prostoru bolesti, već i vanprostornom i vanvremenskom diskursu smrti koje je sve više bila svesna: „Katkad se po njenim riječima moglo vidjeti da misli i na konac. “20 U tim trenucima ona je „izabrana“- od onih je kojima je, rečima Ivana Galeba, ${ }^{21}$ dato da „misle smrt“. Miloš, međutim, nije ontološki predodređen za to, jer je zdrav. Takav, u punoj snazi, ne mogavši da kontemplira - on mora biti stavljen u odgovarajuću narativnu situaciju. Njome se prevazilazi tzv. ikonična argumentacija ${ }^{22}$ - mrtvo telo kao nesavršena kopija živog bića - i zalazi u područje kodne intencije što jasno distingvira prisutno od odsutnog. Prisutna Jagoda i odsutna njena reakcija na muvu - sve to kontrastivno povezuje različite elemente naracije: Jagodu i Miloša, jedinku i svet, život i smrt. Tako u Desničinoj pripoveci muva nije samo obična metafora, ona postaje najznačajniji činilac pripovedanja.

\section{$3 \cdot$}

Ako je u pripoveci Bunarevac svest o smrti transponovana u junaka kao posmatrača, dok je osoba koja umire svedena na telo / leš - onda je u pripoveci Oproštaj, i u završnim poglavljima romana Proljeća Ivana Galeba, Desnica na izrazito naturalistički način pružio sukcesivnu i faznu sliku samoga umiranja, tj. čovekove agonije. Realema ${ }^{23}$ smrti tako je u

17 V. Desnica, „Bunarevac“, 227. Podvukao B. Đ.

18 P. M. Churchland, „Eliminative Materialism and the Propositional Attitudes“, 10.

19 Vladan Desnica, Proljeća Ivana Galeba, Beograd 1993., 451. Podvukao B. Đ.

20 V. DesnicA, „Bunarevac“, 220.

21 V. Desnica, Proljeća Ivana Galeba, 102.

22 Paul Ricoeur, „Writing as a Problem for Literary Criticism and Philosophical Hermeneutics“, A Ricoeur Reader, (ur. Mario Valdés), Toronto - Buffalo 1991., 331.

23 Ovaj termin kao atributiv tzv. fiktivnog narativa uvodimo prema: Itamar Even-ZohaR, „Constraints of Realeme Insertability in Narrative“, Poetics Today, 1/1980., br. 3, 65-74. Detaljno ga razrađuje Brajan Mekhejl. Videti: B. McHale, Postmodernist Fiction, 84-96. 
Desničinoj naraciji opredmećena i istorijski i kulturološki. Istorijski - smrt je činjenica koja bitno određuje ljudsku egzistenciju. Ako se sama smrt kao činjenica i može negirati na filozofsko-teološkoj ravni (pre svega stavom o besmrtnosti duše), dotle se smrt kao realema potvrđuje upravo procesom umiranja koji se nikakvim verovanjem u vrhunaravno biće ne može ni negirati ni transcendentirati. Jer:

I samo to je bog. Bog je naličje smrti. Jedan oblik borbe protiv smrti, i ništa drugo... Svi bezumni pokušaji, sve vrele samoobmane snagom kojih čovjek nadrasta i prevladava smrt - sve je to bog. ${ }^{24}$

Kulturološki - umiranje je proces koji ima svoje tačno određenje, svoje svrhovite i sukcesivne faze. Kao takav, ovaj proces je nužno realističan i samim tim spada u domen „istorijske fikcije“. ${ }^{25}$ Osim toga, ovaj proces je univerzalan, i samim tim repetitivan, pa se i kod Desnice ponavlja. Tako umiranju kao agonički određenom i preciznom narativu bivaju izloženi i Antun, u pripoveci Oproštaj, i Ivan Galeb, u Proljećima Ivana Galeba. Jedina distinkcija je što Antunovu agoniju posmatramo posredstvom naratora koji je u dosluhu sa junakom, a Ivanovu posredstvom naratora koji je sâm junak. U svemu ostalom Desničina istorijska fikcija potpuno je saobrazna kulturnim realemama i kompatibilna sa fizičkim pojavnostima kojima se proces umiranja materijalizuje.

Zalažući se upravo za ovakav realistični prosede i pristup pripovedanju, koji proizlazi iz kulturno i društveno konstruisanog realiteta (stoga Ivan Galeb celoga života nastoji da svoje „misli i zapažanja zaodjen[e] u što nenapadniju, znači u što banalniju formu ${ }^{(26)}$ ), Desnica razume da su izvan tih realema „drugačije stvarnosti“ $i$,enklave unutar vrhovne stvarnosti “. ${ }^{27}$ Stvarnost umiranja Antun opaža dvostruko - kao pounutrašnjenu stvarnost gašenja funkcija sopstvenog tela i uma, i kao eksternu stvarnost ljuštenja maltera sa zida. No, Desnica je suviše dobar pripovedač da bi se zadržao na jednostavnoj analogijskoj simbolici, pa se posle konstatacije o promeni na zidu Antun utapa u nemoć i fluktuaciju sopstvenog „ljuštenja“. Kada i „prijateljska odrtina“ na zidu počne da se zatamnjuje, zatvara se „nevidljiv krug zbivanja“ i nastupa terminalna faza agonije.

Ali, kao što je u prostoru naracije početak agonije jasno lociran, tako su i sve njene faze izdvojene i prepoznate kao niz stanja u koje junak zapada. U mnogo čemu one se poklapaju sa fazama agonije Ivana Galeba pri kraju romana. Jedina razlika je što je Antunova agonija narativno kompaktnija, a njen kontinuitet sačuvan, jer je posredovana pripovedačem. Ivanova agonija je faktualno nestabilnija i narativno razlomljena jer se priča o njoj odvija iz svesti onoga koji tu agoniju proživljava.

Ono što je, međutim, veoma važno, jeste činjenica da se faze agonije Desničinih junaka gotovo u dlaku poklapaju sa terminalnim fazama koju su uočene tokom umiranja neizlečivih bolesnika, a koje u svojoj kapitalnoj studiji sintetiše Elizabet Kjubler Ros. ${ }^{28}$ Jedan od

\footnotetext{
V. Desnica, Proljeća Ivana Galeba, 107.

B. McHale, Postmodernist Fiction, 87.

V. Desnica, Proljeća Ivana Galeba, 202.

P. L. Berger - T. Luckmann, The Social Construction of Reality, 24.

28 Ovu studiju Rosova je prvi put objavila još 1969. godine, i od tada je ona doživela više izdanja. Navode donosimo prema srpskom izdanju: Elizabet KJubler Ros, O smrti i umiranju, Beograd 2010.
} 
referencijalnih pokazatelja agonije jeste bolesnikovo stalno zapadanje u dremež, koji se, doduše, prekida, ali i odmah nastavlja. To uočava Kjubler Ros: „Umoran je i u većini slučajeva slab, pa drema često i nakratko... To je povišena potreba da se produži vreme spavanja - kao kod bebe. ${ }^{\text {(29 }} \mathrm{U}$ takvom stanju nalazi se Antun:

Sve je više zapadao u drijem. U onu nemjerljivu, bezvremenu oazu drijema kojoj kao da nema početka ni kraja. ${ }^{30}$

Takođe i Ivan Galeb:

Ali misao mi se prekida, brzo se zamaram. Drijemam, i kao da sve češće zapadam u neke bijele oaze bez vremena. (...) Sklapam oči i tonem u polusan, u stanje satkano od lijenog odlaganja, od dragovoljnog strpljenja, i od istrganih vlakanaca vremena. ${ }^{31}$

Nastupaju tek kratkotrajni periodi svesti, pre ponovnog potonuća u dremež: „Tek ponekad bolesnik se vraća u spoljašnji svet sa osećajem olakšanja i prihvatanja neminovnosti. ${ }^{\text {“32 }}$ Taj je momenat prisutan i kod Desnice:

Misao bi zamorena, neprimjetno, skliznula sa olakšanjem na što drugo... i najzad se gubila kao potočić u travi. ${ }^{33}$

O kako je to prijatno: isplutati začas iz drijemeža, konstatirati da živiš, pa ponovo, umiren, utonuti u drijemež. ${ }^{34}$

Još jedna odlika ovoga procesa jeste odsustvo temporalnosti. „Gospodin G. nije imao svest o vremenu“, reći će Kjubler Ros. ${ }^{35}$ Subjektivno osećanje samrtnika da vreme ne prolazi postaje za njega fakticitet jači od realne činjenice vremenskog kontinuuma:

Sad nije više ni noć ni dan... Dva-tri dana bez svijesti o bilo kakvom zbivanju, kao preskočene, bijele stranice bez ubilježaba. ${ }^{36}$

Ne znam koliko je dug bio taj časak koji je protekao između onog sklapanja i ponovnog podizanja vjeđa: jedan trenutak ili nekoliko dana.37

Fazu prihvatanja, kako je naziva Kjubler Ros, fazu terminalne agonije kroz koju prolaze Antun i Ivan Galeb, odlikuje i odsustvo emocionalnosti - stanje koje „ne prate gotovo nikakva osećanja“.38 Tačnije, reč je o nemogućnosti da se ona ispolji usled rastrojenosti misli, koja se prepušta svesti o sopstvenoj nemoći i bliskoj smrti:

I kad sklopi oči, sve mu dođe jednako. ${ }^{39}$

Uistinu mi se čini da niti što želim, niti što pravo osjećam. ${ }^{40}$

29 Isto, 92.

30 Vladan Desnica, „Oproštaj“, Pripovetke, 122-123.

31 V. Desnica, Proljeća Ivana Galeba, 450 i 453.

32 E. Kjubler Ros, O smrti i umiranju, 128.

33 V. Desnica, „Oproštaj“, 122.

34 V. Desnica, Proljeća Ivana Galeba, 454.

35 E. Kjubler Ros, O smrti i umiranju, 104.

36 V. Desnica, „Oproštaj“, 123.

37 V. Desnica, Proljeća Ivana Galeba, 451.

38 E. Kjubler Ros, O smrti i umiranju, 92.

39 V. Desnica, „Oproštaj“, 121.

40 V. Desnica, Proljeća Ivana Galeba, 455. 
Gubljenje veze sa spoljnim svetom ima dvostruki smisao. Kjubler Ros piše: „Pošto je pacijent našao mir u prihvatanju, sve manje spoljnih stvari ga interesuje i ne želi da bude uznemiravan vestima i problemima. Posetioci često nisu dobrodošli..." ${ }^{\text {“1 }} S$ jedne strane, dakle, to je posledica otupelosti posle perioda patnje i bolova. $S$ druge, to je gotovo metafizička svest o efemernosti pojavnih stvari i taštih ljudskih potreba i sudbina:

Sve se izmaknulo van njegova dohvata. Malo predsoblje bilo je drugi svijet. Hodnik - predvorje nepoznatog. A kuhinja - do nje su daleki i zamorni puti i za samu misao! (...) Uopće, sve što se očima gleda i spoznava, ne postoji. ${ }^{42}$

Svrstavaju se u jednu ravninu, svi jednako važni odnosno nevažni, svi jednako živi odnosno neživi. ${ }^{43}$

Prestanak bola posledica je koliko medicinskog tretmana - lekova i morfijuma ${ }^{44}$ - toliko i samrtnikovog prihvatanja konačnosti: „Bolovi kao da su prestali, borba se završila. “45 Slično nalazimo i u Proljećima Ivana Galeba:

Samo ne više patnje! Probudim se u noći i skrušeno šapućem: samo ne više patnje! $!^{46}$

Pa ipak, tanka linija života još se ne da preći tako lako. Ni Antunom ni Ivanom još ne ovladava ona rezigniranost predaje. Ambivalencija njihovog dugotrajnog stanja bolesti nagoni ih na makar podsvesnu, makar agonijom i lekovima posredovanu, borbu, koja je sada svedena na misao o trajanju - ako ne sopstvenom, onda trajanju onih realema koje su činile i njihov svet. I tu je Desnica pokazao dobro poznavanje psihologije samrtnika:

To nije bespomoćno i rezignirano predavanje uz pitanje „,̌emu više“ ili „,ne mogu više da se borim“... To još uvek ne znači da bolesnik prihvata svoju sudbinu. ${ }^{47}$

U Antunovom umu taj osećaj nepristajanja posredovan je zvukom, „srebrnom niti“, koji možda i ne postoji ali ga Antun svojim unutarnjim uhom čuje, i vezuje se za njega u želji da produži trajanje:

Tanji se, blijedi, sad ga čuješ - sad se izgubi, pritaji se, ali nezavisno od tebe, nezavisno od toga da li ga ti čuješ ili ne čuješ, on traje, traje... ${ }^{48}$

To trajanje kao antipodni pandan umiranju biva ideal i Ivana Galeba:

Ipak, ne želim potpuno spokojstvo, potpuno mrtvilo. To ne! Volim da vrhom spuštenih trepavica osjećam vanjsko trajanje, protjecanje stvarnosti. Samo da ja ostanem izvan njega,

\footnotetext{
E. KJubler Ros, O smrti i umiranju, 93.

V. Desnica, „Oproštaj“, 121-122.

3 V. Desnica, Proljeća Ivana Galeba, 456.

44 Uporedi, na primer, sledeće citate: „I Antun i Ivan Galeb bivaju trgnuti iz dremeža i izmaglice misli zahvaljujući injekcijama: Doktor umotava špricu i iglu u bijelu krpicu i sprema u metalnu kutiju..." (V. Desnica, „Oproštaj“, 124) i „Opet transfuzija krvi. Ubod u lijevu podlakticu“ (V. Desnica, Proljeća Ivana Galeba, 459).

45 E. KJubler Ros, O smrti i umiranju, 92.

46 V. Desnica, Proljeća Ivana Galeba, 458.

47 E. KJubler Ros, O smrti i umiranju, 92.

48 V. Desnica, „Oproštaj“, 123.
} 
da ne učestvujem u njemu. Jer, biti u njemu, učestvovati u njemu, to je previše zamorno. Ali neka ono ipak traje. Neka samo traje, neka promiče mimo mene. ${ }^{49}$

Šta je, međutim, to što i Antuna i Ivana Galeba drži na granici života i smrti, bića i tela, šta je to što fikcionalni svet pripovedanja u Desničinoj pripoveci Oproštaj i romanu Proljeća Ivana Galeba čini „argumentovanim prostorom junakove egzistencije“, ${ }^{0}$ koji se postvaruje čvornim tačkama preloma? To je potreba za drugim i svest o prisustvu drugog kao veze sa spoljnim svetom. To je više od utehe ili simboličke oznake empatije:

Bolesnik nije raspoložen za razgovor i traži prisustvo određene osobe. Ona treba da ga uzme za ruku ili samo da bude prisutna... Pacijent se fiksira na određenu osobu i može da ga prene samo prisustvo te osobe. ${ }^{51}$

Za Antuna - to je Ana. Neodređena emocija koju on oseća prema staroj dvorkinji transformiše se u osećaj njenog postojanja. Ona je više od veze sa stvarnim svetom i okolinom, od koje se samrtnik postepeno odvaja. Ona je „nadneseno lice sa dva velika oka kao dva sunčana časovnika“ ${ }^{52}$ Ona je i stalno bivanje - egzistencijalni korektiv emocionalnog diskursa umiranja, ${ }^{53}$ neko ko stoji po strani i vrši obrnutu funkciju htonskog bića. Jer, dok se u mitološkoj predstavi takvo biće pojavljuje da samrtnika prevede u podzemlje, u drugi svet, dotle Ana, orfejski, Antuna prevodi iz drugog sveta nazad, u svet živih. Zato je tu, ali sa strane, kao treća osoba - između Antuna i Smrti:

Otvori umorno oči i vidi podno kreveta Anu - donijela mu čašu topla čaja i zove ga; a on ne zna da li je to sad ušla u sobu i zazvala ga, ili je već odavna tu pored njega i zove već po treći, četvrti put... Ponovno kao da ga neko zove. Vjeđe se teško rasklapaju - Ana je tu, u svojoj vunenoj kapi i kaputu... ${ }^{54}$

Za Ivana Galeba, pak, to mitsko biće koje ga prevodi u stanje svesti o sebi i životu jeste bolničarka - koja, kao i Ana prema Antunu, naginje lice prema Ivanu, a njen glas je funkcionalni pandan onom zvuku koji čuje Antun, i koji svedoči o trajanju:

Ponekad, opet, čujem nad sobom jedan glas. Prodro je do moje svijesti svojom upornošću. A ta upornost sastoji se u tome što više puta ponavlja jedno te isto. Nametnuo mi se tom upornošću ponavljanja... Najzad otvaram oči i vidim nad sobom lice bolničarke i njene usne što se miču. Da, sad mi je jasno da je taj glas bio prisutan još prije nego što sam ga počeo razabirati; da je on i bio ono što me iznosilo, polako, kao na rukama, sa dna moje besvjesti na površinu... Ponovo ugledam nad sobom poznato lice i usne što se miču... ${ }^{55}$

I baš to - prisustvo drugog - biva ona narativna situacija koju Desnica vešto gradi da bi svoje junake izveo u svet van šterbecimera. Oni, paradoksalno, u istorijskoj fikciji umiru

\footnotetext{
49 V. Desnica, Proljeća Ivana Galeba, 454.

50 Jerome Bruner, Actual Minds, Possible Worlds, Cambridge, Massachusetts 1986., 113.

51 E. Kjubler Ros, O smrti i umiranju, 93. Podvukao B. Đ.

52 V. Desnica, „Oproštaj“, 123.

53 Derek Edwards, „Emotion Discourse“, Culture \& Psychology, 5/1999., br. 3, 284.

54 V. Desnica, „Oproštaj“, 123. Podvukao B. Đ.

55 V. Desnica, Proljeća Ivana Galeba, 451. Podvukao B. Đ.
} 
- ali u tzv. aistorijskoj fikciji ${ }^{56}$ i dalje bivaju, dakle osećaju i kontempliraju. Naznake smrti i dalje su prisutne. Tako Antun u pripoveci Oproštaj „liježe uređen i smireno čeka“. 57 Ali koga? Smrt ili Anu? A Ivan Galeb, takođe pomiren, oseća da „sve želje šute i čula dremlju, a misli imaju prazničko ruho i bijele skrštene ruke" ${ }^{58} \mathrm{~A}$ kada se leži, kada se na sebi ima svečana odeća i kada su ruke skrštene - onda je jasno da je fakticitet smrti zapremio čitavo narativno polje. Antun i Ivan Galeb su, za razliku od Jagode - jer Miloš nije bio obdaren htonskim moćima percepcije drugog, koje bi poslužile da se taj drugi prevede na ovu stranu - izašli iz šterbecimera, ali to ne znači da se njihovom gornjom usnom nije već prošetala muva. I da „tekstualni stvarni svet ${ }^{\text {" } 59}$ Desničine proze nije, konačno i neopozivo, prostor Tanatosa.

\section{$\cos$}

\section{Izvori i literatura}

\section{Izvori}

Vladan Desnica, „Bunarevac“, Pripovetke, Beograd 1993., 181-229.

Vladan DesnicA, „Oproštaj“, Pripovetke, Beograd 1993., 118-125.

Vladan Desnica, Proljeća Ivana Galeba, Beograd 1993.

\section{Literatura}

Peter L. Berger - Thomas Luckmann, The Social Construction of Reality. A Treatise in the Sociology of Knowledge, New York 1966.

Jerome Bruner, Actual Minds, Possible Worlds, Cambridge, Massachusetts 1986.

Paul M. Churchland, „Eliminative Materialism and the Propositional Attitudes“, A Neurocomputational Perspective. The Nature of Mind and the Structure of Science, Cambridge, Massachusetts 1989., 1-22.

Dorrit CoHn, Transparent Minds. Narrative Modes for Telling Consciousness in Fiction, Princeton 1978.

Samuel R. Delany, „About 5750 words“, The Jewel-Hinged Jaw. Notes on the Language of Science Fiction, Elizabethtown, New York 1977., 25-42.

Derek Edwards, „Emotion Discourse“, Culture \& Psychology, 5/1999., br. 3, 271-291.

Itamar Even-ZohaR, „Constraints of Realeme Insertability in Narrative“, Poetics Today, 1/1980., br. 3, 65-74.

Edmund Husserl, „Ideen zu einer reinen Phänomenologie und phänomenologischen Philosophie“, Jahrbuch für Philosophie und phänomenologische Forschung, 1/1913., sv. 1, 1-323.

Zoltan Kanjo, „Prilog proučavanju početka pripovednog teksta“, Reč, 2/1995., br. 13, 97-105.

Elizabet KJubler Ros, O smrti i umiranju, Beograd 2010.

56 Marie-Laure Ryan, „Possible Worlds and Accessibility Relations: A Semantic Typology of Fiction“, Poetics Today, 12/1991., br. 3, 11.

57 V. Desnica, „Oproštaj“, 125.

58 V. Desnica, Proljeća Ivana Galeba, 466.

59 Marie-Laure Ryan, „The Modal Structure of Narrative Universes“, Poetics Today, 6/1985., br. 4, 723. 
Lee T. Lemon - Marion J. Reis (prir.), Russian Formalist Criticism. Four Essays, Lincoln 1965.

Uri Margolin, „Individuals in Narrative Worlds: An Ontological Perspective“, Poetics Today, 11/1990., br. 4, 843-871.

Brian McHale, Postmodernist Fiction, New York - London 1987.

Paul Ricoeur, „Writing as a Problem for Literary Criticism and Philosophical Hermeneutics“, $A$ Ricoeur Reader (ur. Mario J. Valdés), Toronto - Buffalo 1991., 320- 337.

Marie-Laure Ryan, „Possible Worlds and Accessibility Relations: A Semantic Typology of Fiction“, Poetics Today, 12/1991., br. 3, 553-576.

Marie-Laure Ryan, „The Modal Structure of Narrative Universes“, Poetics Today, 6/1985., br. 4, 717-755.

\section{$\cos$ \\ THE FLY ON HER UPPER LIP: THE NARRATIVE SPACE OF DEATH IN VLADAN DESNICA'S FICTION}

Desnica's historical fiction is realized in the narrative approach to death and dying. In that narrative field, the relationship between the fictional and the real is akin to an allegorical image of a curtain rising in the theater, with the agony of death being parallel to the dropping curtain, after which the literary hero and the narrator, as well as the reader, are "transported" into the "supreme reality of everyday life". Thus, Desnica actually achieves a sort of an informal approach to the fictional discourse, whose logic does not necessarily match the real. What Delany would refer to as "a level of subjunctivity" is in fact the narrator's attempt to conform the perceptional and the structural postulates of narration to the narrator's perspective, from which an implication conforming to the narrative logic will be derived. Such an approach to the process of dying is best illustrated by the short stories Bunarevac and Oprostaj (The Parting), as well as the final chapters of the novel Proljeća Ivana Galeba (The Springs of Ivan Galeb). Jagoda's death in Bunarevac is the culmination of a Chekhovian atmposphere of senslessness and futility. Milošs chagrin over his wasted life and inability to do something useful reaches its high point in the moment of Jagoda's death. The narrator avoids focusing on the details of her expiring, bringing that much more exposure to the image of Jagoda in her death. Free of pain and suffering, in that moment Jagoda becomes the total opposite of her husband. Jagoda's body becomes an objective, existential fact and although it does of suggest a certain spiritual and emotional state for Miloš, this state manifests itself only occasionally, determined by the obvious incomprehension of death as a pure fact. The hero's raised awareness of the simulacrum as the immitation of a being, a subjective image of Jagoda which is inevitably different from Jagoda as a body, the awareness of the difference between the real and the iconic, is emphasized by an almost folkloric (due to its realism) image of the fly as the sign of death. It is only the presence of the fly and the absence of a natural, living reaction to the stimulus that it represents which testify to death as a fact, whose finality had heretofore escaped the hero. The presence of Jagoda combined with the absence of her reaction to the fly juxtapose different elements of narration: Jagoda and Miloš, the individual and the world at large, life and death. In Desnica's story, the fly is more than just a metaphor: it becomes the central narrative element. If the awareness of death is transposed into the hero as the observer in Bunarevac, while the dying person is reduced to a dead body, then the short story Oproštaj (The Parting) and the novel Proljeća Ivana Galeba (The Springs of Ivan Galeb) provide a successive, phase image of dying itself, i.e. the agony of death. Therefore, the realem of death becomes historically and culturally reified in Desnica's 
narration. However, just as the beginning of the agony is clearly located within the narrative, so are all its stages isolated and recognised as a series of states the hero is endures. In many ways, they correspond to the stages of Ivan Galeb's agony at the end of the novel. The only difference is that Antun's suffering is narratively more compact, and its continuity intact, seeing as it is mediated the narrator. Ivan's suffering is factually less stable and more narratively fractured because the story about it takes place in the consciousness of the one who is enduring it. The stages of agony that Desnica's heroes go through correspond almost exactly with the stages of grief observed in terminally ill patients and described by Elizabeth Kübler-Ross in her capital study On Death and Dying. Unlike Jagoda, Antun and Ivan Galeb exit the Sterbezimmer, but that does not mean that the fly has not already walked over their upper lip. Thus the narrative space in Desnica's fiction is, in the end revealed to be the space of Thanatos.

Key words: narration, death, dying, the body, space, duration 